\title{
Stigma and Attitudes towards Psychiatric Patients in Portuguese Medical Students
}

\author{
Estigma e Atitudes para com Doentes Mentais em Estudantes de Medicina
}

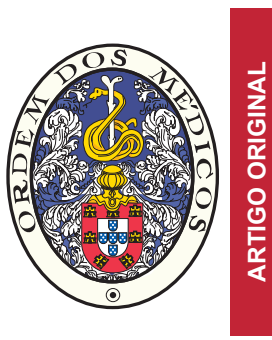

\author{
Diogo TELLES-CORREIA ${ }^{1}$, João GAMA MARQUES $\triangle^{1,2}$, João GRAMAÇA ${ }^{1}$, Daniel SAMPAIO ${ }^{1}$ \\ Acta Med Port 2015 Nov-Dec;28(6):715-719
}

ABSTRACT

Introduction: This study aims to assess the impact of psychiatric education on attitudes of medical students towards psychiatric patients.

Material and Methods: A cross-sectional survey of medical students was conducted at the biggest Portuguese medical school. The students completed an anonymous self-report questionnaire, including sociodemographic data, family history of psychiatric illness, and the Community Attitudes toward the Mentally III scale.

Results: Of the 2178 students, 398 answered the survey, representing $18.2 \%$ of the whole medical school. There was a significant improvement in all Community Attitudes toward the Mentally III scale dimensions along the medical course. The higher scores were in Restrictiveness subscale (38.01), and the lower scores were for Authoritarianism (36.13). The best improvement along the course was for Authoritarianism $\left(5^{\text {th }}\right.$ year score $-1^{\text {st }}$ year score $\left.=2.03\right)$, and the worse was for Benevolence $\left(5^{\text {th }}\right.$ year score $-1^{\text {st }}$ year score $\left.=0.39\right)$. The biggest improvement, in all scores, was found at the end of the 3rd year.

Discussion: The authors propose that the better attitudes found on third year students were due to a very specific anti-stigma module on the theoretical discipline 'Introduction to Mental Health'. After that, this positive effect was lost, with fourth and fifth year medical students showing a worsening of their attitudes.

Conclusion: Our results highlight the importance of anti-stigma specific education modules in order to improve students' attitudes toward mental health. Thus more anti-stigma preventive measures can be taken onward, on preparing the best way possible, the next generation of doctors.

Keywords: Attitude; Psychiatry; Social Stigma; Students, Medical.

\section{RESUMO}

Introdução: Este estudo pretende avaliar o impacto da educação psiquiátrica nas atitudes em alunos de medicina face aos doentes mentais.

Material e Métodos: Foi conduzido um inquérito em corte transversal na maior faculdade de medicina portuguesa. Os alunos preencheram um questionário que incluía informação sociodemográfica, antecedentes pessoais e familiares de doença psiquiátrica, bem como a Community Attitudes towards the Mentally III scale.

Resultados: Em 2178 estudantes, 398 responderam ao inquérito, representando 18,2\% daquela faculdade de medicina. Houve uma significativa melhoria em todas as dimensões avaliadas pela Community Attitudes towards the Mentally III scale, ao longo dos anos do curso de medicina. Os valores mais elevados verificaram-se na subescala Restritividade $(38,01)$, e os valores mais baixos na sub-escala Autoritarismo $(36,13)$. A melhor diferença verificou-se para a sub-escala Autoritarismo $\left(5^{\circ}\right.$ ano $-1^{\circ}$ ano $\left.=2,03\right)$, e a pior diferença verificou-se para a sub-escala Benevolência $\left(5^{\circ}\right.$ ano $-1^{\circ}$ ano $\left.=0,39\right)$. Os melhores resultados foram encontrados no final do $3^{\circ}$ ano. Discussão: Os resultados poderão dever-se ao módulo de luta contra o estigma, incluído na disciplina de 'Introdução à Saúde Mental'. Esse efeito positivo ter-se-á perdido no $4^{\circ}$ e $5^{\circ}$ anos, com uma degradação das atitudes.

Conclusão: Este estudo salienta a importância dos módulos de luta contra o estigma na melhoria das atitudes dos estudantes de medicina perante a saúde mental. Este tipo de acções pedagógicas preventivas com intuito anti-estigma, devem ser na melhor preparação possível de gerações médicas futuras.

Palavras-chave: Atitude; Estigma Social; Estudantes de Medicina; Psiquiatria.

\section{INTRODUCTION}

Stigma has been defined in many different ways. Some authors define it as a sign of disgrace or discredit that sets a person apart from others. ${ }^{1}$ Other authors proposed that stigma exists when elements of labeling, stereotyping, separating, status loss and discrimination co-occur in a power situation that allows these processes to unfold. ${ }^{2}$

Stigma and discrimination cause a significant burden for people suffering from psychiatric disorders. ${ }^{3}$ In the last years many tools have been used to assess stigmatizing attitudes towards the psychiatric patients. ${ }^{4-9}$ Unfortunately

negative attitudes towards the people with a psychiatric diagnosis are not confined to the lay public, but are also common among health professionals. ${ }^{10,11}$ Medical doctors in general, and not only Psychiatrists have contact with people with psychiatric diagnosis and medical education has an important role in reducing these negative attitudes in these professionals.

Like the general public, medical students often hold the stereotypical views that people with psychiatric diagnosis are unlikely to recover and can be dangerous. ${ }^{12}$ It has been

\footnotetext{
1. Clínica Universitária de Psiquiatria e Psicologia Médica. Faculdade de Medicina. Universidade de Lisboa. Lisboa. Portugal.

2. Clínica de Psicoses Esquizofrénicas. Hospital Júlio de Matos. Centro Hospitalar Psiquiátrico de Lisboa. Lisboa. Portugal.

$\square$ Autor correspondente: João Gama Marques. joaogamamarques@gmail.com

Recebido: 25 de Janeiro de 2015 - Aceite: 03 de Agosto de 2015 | Copyright @ Ordem dos Médicos 2015
} 
reported that $28 \%$ of medical students thought that people with psychiatric disorder 'are not easy to like' and that $78 \%$ considered people with schizophrenia to be dangerous and violent. ${ }^{13}$

The knowledge and attitudes of undergraduate medical students towards psychiatric disorders is out utmost importance as these individuals will be involved in the care of these patients throughout their careers. For more than forty years investigators have been interested in medical students' attitudes towards the psychiatric patients, but only in the last ten years the investigational works have become more elaborated ${ }^{14}$ and many studies have attempted to characterize the attitudes of medical students towards the patients with psychiatric diagnosis in different countries. ${ }^{15,16}$

Medical students are introduced to mental health issues in different ways, depending on the country. In Portugal, students are introduced to these issues mainly through the psychiatry disciplines (where they receive psychiatric education and training). This is, to our knowledge, the first Portuguese study among medical students.

There is some controversy about the impact of undergraduate psychiatric education and training on medical students' attitudes about psychiatric disorders. ${ }^{17}$ Some authors have found that the psychiatric undergraduate training might have a mixed effect in terms of both positive and negative changes in medical student's attitudes. ${ }^{18}$

Positive effects can be due to the information and education about psychiatric disorders received, and the negative effects may be due to the iatrogenic stigma of psychiatric diagnosis, e.g. the stigma that 'begins with behavior and attitudes of medical professionals, especially psychiatrists'. ${ }^{19}$ Thus some authors suggest that inclusion of a specific anti-stigma training module as part of the undergraduate training course in psychiatry may be a valid tool. ${ }^{20}$

The present study aimed to assess the impact of psychiatric education and training on attitudes of medical students towards patients with psychiatric diagnosis comparing medical students across different years on this issue. We hypothesize that the attitudes of undergraduate medical students towards psychiatric disorders can be different depending on the year they attend, and that an anti-stigma specific module included in the $3^{\text {rd }}$ year program of our medical school, could have some impact in these attitudes.

\section{MATERIAL AND METHODS}

This was a cross-sectional designed study. A group of 398 medical students ( 84 from the $1^{\text {st }}$ year, 97 from the $2^{\text {nd }}$ year, 71 from the $3^{\text {rd }}$ year, 91 from the $4^{\text {th }}$ year and 55 from the $5^{\text {th }}$ year), belonging to the Faculty of Medicine of the University of Lisbon (FMUL) were assessed. At that time those 398 students represented $18.2 \%$ of all the FMUL population (2 178 students). Written informed consent was obtained from all participants, and the study protocol was approved by the institutional review committee. All the students were surveyed at the end of their respective years.
In this faculty, as in the other Portuguese medical faculties, training and education in psychiatry is given to students by means of four different disciplines. In the second year students attend 'Medical Psychology', where they learn the neuroanatomical and physiological basis of behaviour, and they have little physical contact with patients. In the third year, they attend 'Introduction to mental health'. The discipline 'Introduction to Mental Health' consists of 26 classes, 13 of them theoretical (explanation of theories and concepts) and 13 practical (include direct contact with psychiatric patients). Ten of these classes (5 theoretical and 5 practical) are directly related to anti-stigma matters: 1 -The meaning of mental health; 2 - Living with mental problems; 3 - Coping with mental problems; 4 - Rehabilitation of mental illness; 5 - Prevention of mental illness.

In the fourth and fifth years students attend 'Psychiatry I' where they learn psychopathology and nosology, and 'Psychiatry II' where they learn the basis of custom psychopharmacological treatment.

A demographic questionnaire asked for details of age, sex, nationality, marital status, if they had children, prior psychiatric treatment and whether person had had contact with a relative with a psychiatric diagnosis. To assess medical students' attitudes about psychiatric disorders, the Community Attitudes towards the Mentally III scale (CAMI) was used. This is a questionnaire created by Taylor and Dear in 1981, ${ }^{21}$ consisting of forty statements, each requiring a rating of the participants degree of agreement/ disagreement on a five point Likert scale (with anchors 1 = strongly disagree to $5=$ strongly agree) and yields four attitude factor scores, each calculated by adding the ten relevant items and then dividing them by ten, to obtain a mean score for each factor. A higher factor score indicates a more favorable attitude. In our sample a good reliability was found for the total scale (0.75) and for each subscale: Authoritarianism: Cronbach alpha 0.84; Benevolence: Cronbach alpha 0.87; Social Restrictiveness: Cronbach alpha 0.81; and Community Mental Health Ideology Cronbach alpha 0.85 .

This instrument has already been translated, validated and used in different countries, including Portugal. ${ }^{22}$ In this scale there are four sub-scales that are used to assess four different kind of attitudes: Authoritarianism: reflects a view of the 'mentally ill' as an inferior class requiring coercive handling; Benevolence: reflects a sympathetic view of those suffering a 'mental illness' based on humanistic and religious principles; Social Restrictiveness: reflects a view of the 'mentally ill' as a threat to society; and Community Mental Health Ideology (CMHI): reflects a view that recognizes the therapeutic value of the community and acceptance of deinstitutionalized care.

Statistical analyses were performed with the SPSS 13.0 for Windows software package. Descriptive data were presented in absolute frequencies, percentages and mean values. Comparison of sociodemographic variables between the different years was performed by means of Kruskal-Wallis and $\chi^{2}$ tests. Comparison of CAMI 
scores from different years was performed by means of Kruskal-Wallis test $(p<0.05$ was considered statistically significant). Nonparametric tests were used because a normal distribution was not found by means of KolmogorovSmirnov test.

\section{RESULTS}

Demographic characteristics of the sample are displayed in Table 1.

There were better results in all CAMI dimensions in later medical course years. The higher scores were for the Restrictiveness subscale (38.01), and the lower scores were for Authoritarianism (36.13). The best improvement along the medical course was for Authoritarianism ( $5^{\text {th }}$ year score $-1^{\text {st }}$ year score $=2.03$ ), and the worse one was for Benevolence $\left(5^{\text {th }}\right.$ year score $-1^{\text {st }}$ year score $\left.=0.39\right)($ Table 2).

The biggest improvement was in the end of the $3^{\text {rd }}$ year, and after that, there was a decrease in all the scores, even though they never returned to the initial values (Fig. 1). Probably the great statistical significance found in KruskalWallis test was due to this difference.

\section{DISCUSSION}

The main limitations of this study were the crosssectional approach and the bias on the sample selection, as we had a very small and limited sample.

Because of differences between studies' methodology it is difficult to compare results among different medical students' populations around the world. Portuguese medical students have similar results to some studies that showed good or better attitudes towards the psychiatric patients in late medicine school years, ${ }^{23}$ after psychoeducation ${ }^{24-29}$ and psychiatric teaching..$^{30-32}$ Although our students' attitudes showed a regression in scores after the third year, they were still better at the end of the course than the in first year. Anyway we shall be aware of the bias of age, as older students may have better attitudes when compared to younger students.

We propose that the better attitudes found in third year students were due to a very specific anti-stigma module on our discipline 'Introduction to Mental Health'.

Afterwards these better attitudes effect seemed to be lost, with fourth and fifth year medical students showing a worsening of their attitudes. That result might be secondary to the contact with real world psychiatric patients, and the diagnosis and treatment oriented teachings on disciplines as 'Psychiatry I' and 'Psychiatry II', respectively.

Another important issue might also be the contamination of negative attitudes towards the psychiatric patients from teachers to students, on daily clinical praxis of late medicine school years. This kind of phenomena has been described by other authors, especially among psychiatrists, and seems related with the stigma linked with the psychiatric diagnosis and treatment. ${ }^{33}$ Although negative attitudes towards psychiatry and psychiatrists may be well established before medical school enrollment ${ }^{34}$ some medical students may also be influenced by negative attitudes held towards psychiatry and psychiatrists by their medical educators. ${ }^{35}$

Therefore we believe the positive effect seen in the CAMI results at the end of the third year might be due to the positive effect of the direct anti-stigma modules of

Table 1 - Main results in our sample

\begin{tabular}{lcccccc} 
Year & $\mathbf{1}^{\text {st }}$ & $\mathbf{2}^{\text {nd }}$ & $\mathbf{3}^{\text {rd }}$ & $\mathbf{4}^{\text {th }}$ & $\mathbf{5}^{\text {th }}$ & \\
\cline { 1 - 5 } $\mathbf{N}$ & $\mathbf{8 4}$ & $\mathbf{9 7}$ & $\mathbf{7 1}$ & $\mathbf{9 1}$ & $\mathbf{5 5}$ & \\
\hline Mean Age & 19.36 & $\mathbf{2 0 . 6 2}$ & $\mathbf{2 1 . 9 0}$ & $\mathbf{2 2 . 6 1}$ & $\mathbf{2 4 . 4 6}$ & Chi-Sq 229.4; $p<0.001 ;$ Kruskal-Wallis \\
Male (\%) & 33.33 & 32.98 & 28.16 & 32.96 & 42.01 & Pears. Chi Sq 6.92; $p=0.14 ; \chi^{2}$ \\
Portuguese (\%) & 91.66 & 96.90 & 97.18 & 97.80 & 93.33 & Pears. Chi Sq 5.53; $p=0.23 ; \chi^{2}$ \\
Single (\%) & 92.85 & 91.75 & 88.73 & 96.70 & 91.11 & Pears. Chi Sq 14.27; $p=0.28 ; \chi^{2}$ \\
Children (\%) & 2.38 & 4.13 & 2.81 & 2.19 & 2.22 & Pears. Chi Sq 15.33; $p=0.22 ; \chi^{2}$ \\
Substance use (\%) & 11.90 & 10.30 & 4.22 & 8.79 & 17.78 & Pears. Chi Sq 28.80; $p=0,42 ; \chi^{2}$ \\
Previous psychiatric treatment (\%) & 2.38 & 4.13 & 2.81 & 2.19 & 4.93 & Pears. Chi Sq 12.68; $p=0.39 ; \chi^{2}$ \\
Psychiatric illness in relatives (\%) & 40.46 & 45.36 & 50.70 & 52.74 & 44.44 & Pears. Chi Sq 4.05; $p=0.40 ; \chi^{2}$ \\
\hline
\end{tabular}

Table 2 - CAMI results and comparison of scores from different years

\begin{tabular}{lcccccccc}
\hline CAMI sub-scales & Total & $\mathbf{1}^{\text {st }}$ Year & $\mathbf{2}^{\text {nd }}$ Year & 3 $^{\text {rd }}$ Year & $\mathbf{4}^{\text {th }}$ Year & $\mathbf{5}^{\text {th }}$ Year & Chi-Sq & $\boldsymbol{p}^{\text {P }}$ \\
\hline Authoritarianism & 36.13 & 35.17 & 36.08 & 38.15 & 36.90 & 37.20 & 40.49 & 0.000 \\
Benevolence & 36.68 & 36.31 & 36.40 & 38.22 & 36.40 & 36.70 & 14.93 & 0.005 \\
Restrictiveness & 38.01 & 36.89 & 37.70 & 40.26 & 37.90 & 38.26 & 27.93 & 0.000 \\
CMHI & 37.76 & 36.41 & 37.08 & 39.95 & 37.76 & 37.97 & 25.69 & 0.000 \\
\hline
\end{tabular}

CAMI: Community Attitudes towards the Mentally III scale; $\mathrm{CMHI}$ : Community Mental Health Ideology. 


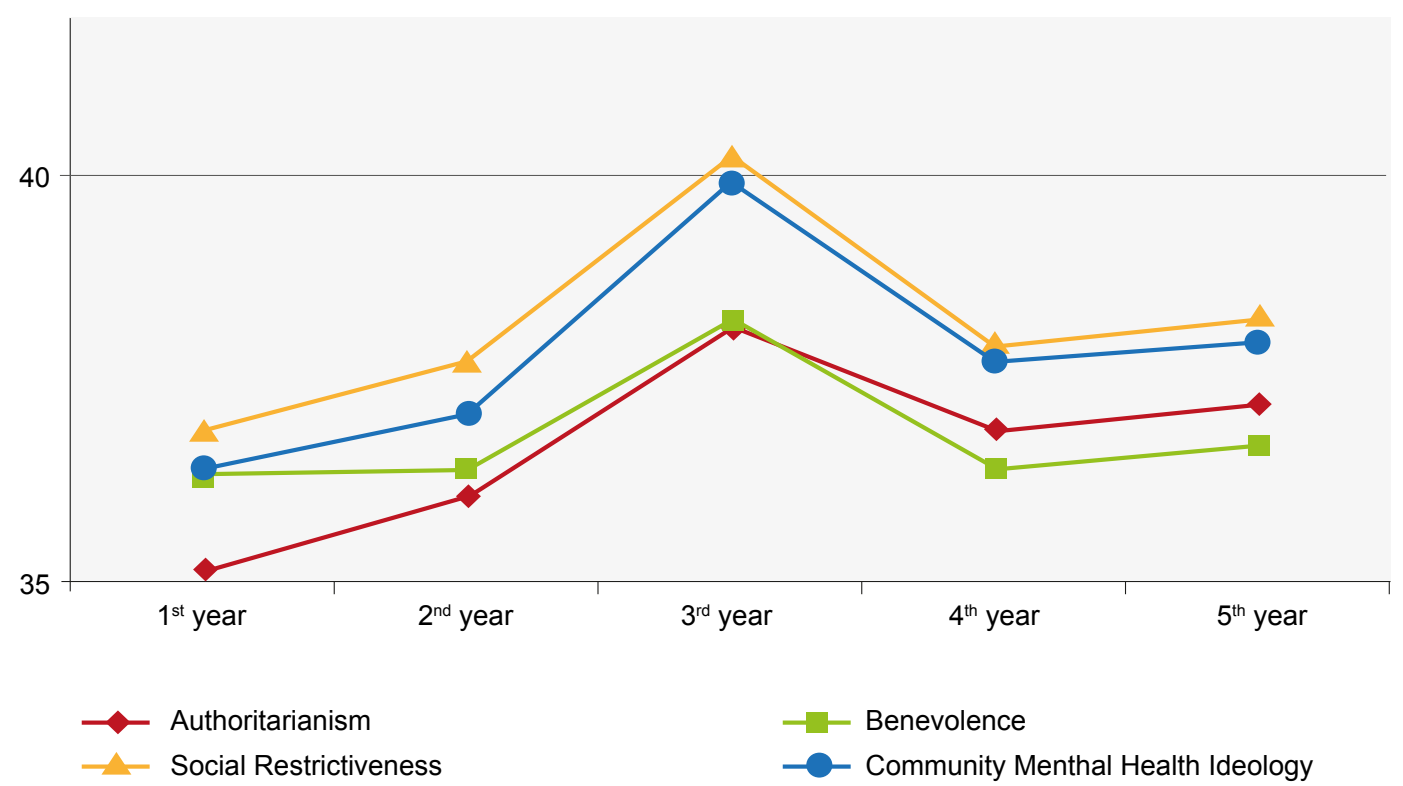

Figure 1 - CAMI subscales results according to year of medical students

the discipline 'Introduction to Mental Health'. The positive impact of specific anti-stigma education modules was found by other authors. ${ }^{10,13,20}$ Nevertheless this positive impact wasn't long lasting and this could be due, as stated, to contamination of negative attitudes towards the psychiatric disorders from teachers to students and negative attitudes held towards psychiatry and psychiatrists by their medical educators, among other factors that are mostly present in late medicine school years. ${ }^{28,30,31}$

\section{CONCLUSION}

Our results highlight the importance of anti-stigma specific education modules in order to improve medical students' attitudes towards mental health. This could be important to improve the quality of clinical, technical and relational skills of these medical students in the future. ${ }^{36,37}$

Further and more detailed studies are recommended to assess the need for academic measures to fight negative attitudes and stigma against psychiatric patients among medical students.

According to our study, the stigma towards psychiatric patients experienced by medical students can change throughout the medical course. Therefore, it could be important to test the impact of the specific anti-stigma modules not only in the beginning but also all over the years of medical education, eventually integrating these modules in other disciplines.

It could also be interesting to investigate the impact of these anti-stigma modules in the way of coping with psychiatric symptoms ${ }^{38}$ of students themselves, or in the ones with relatives with a psychiatric diagnosis. Could these modules improve protective coping strategies such as helpseeking or prevent negative coping strategies like treatment discontinuation?
Further studies can, as well, be developed to explore the many other aspects that can influence medical students' stigma towards psychiatric disorders and/or patients beyond the academic disciplines. One of these aspects can be, as stated, the contamination of negative attitudes from teachers to students, towards the psychiatric disorders.

\section{ACKNOWLEDGMENTS}

This research received no specific grant from any funding agency in the public, commercial, or not-for-profit sectors.

The authors want to acknowledge Teresa Mósca, clinical psychologist at Hospital Júlio de Matos, Centro Hospitalar Psiquiátrico de Lisboa, for all the help regarding the Portuguese version of CAMI.

\section{PROTECTION OF HUMANS AND ANIMALS}

The authors declare that the procedures were followed according to the regulations established by the Clinical Research and Ethics Committee and to the Helsinki Declaration of the World Medical Association.

\section{DATA CONFIDENTIALITY}

The authors declare having followed the protocols in use at their working center regarding patient's data publication.

\section{CONFLICTS OF INTEREST}

The authors declare that there are no conflicts of interest.

\section{FUNDING SOURCES}

No subsidies or grants contributed to this work. 


\section{REFERENCES}

1. Ostman M, Kjellin L. Stigma by association: psychological factors in relatives of people with mental illness. Br J Psychiatry. 2002;181:494-8.

2. Link B, Phelan J. Conceptualizing stigma. Ann Rev Sociol. 2001;27:36385.

3. Sartorius N. Stigma: what can psychiatrists do about it? Lancet. 1998;352:1058-9.

4. Angermeyer MC, Matschinger $\mathrm{H}$. The effect of personal experience with mental illness on the attitude towards individuals suffering from mental disorders. Soc Psychiatry Psychiatr Epidemiol. 1996;31:321-6.

5. Kheirabadi G, Yousefi F, Vafaei F. Attitude towards mental illness in Sanandaj. Sci J Kurdistan Univ Med Sci. 1997;2:14-7.

6. Chowdhury AN, Sanyal D, Dutta Sk, Banerjee S, De R, Bhattacharya $\mathrm{K}$, et al. Stigma and mental illness: pilot study of laypersons and health care providers with the EMIC in rural West Bengal, India. Int Med J. 2000;7:257-60.

7. $\mathrm{Ng} \mathrm{P}$, Chan KF. Sex differences in opinion towardss mental illness of secondary school students in Hong Kong. Int J Soc Psychiatry. 2000;46:79-88

8. Watson AC, Otey E, Westbrook $A H$, Qardner AL, Lamb TA, Corrigan PW, et al. Changing middle schoolers' attitudes about mental illness through education. Schizophr Bull. 2004;30:563-72.

9. Luty J, Fekadu D, Umoh O, Gallagher J. Validation of a short instrument to measure stigmatized attitudes towards mental illness. Psychiatr Bull. $2006 ; 30,257-260$.

10. Corker E. Stigma caused by psychiatrists. Br J Psychiatry. 2001;178:379

11. Ucok A, Polat A, Sartorius N, Erkoc S, Atakli C. Attitudes of psychiatrists towards schizophrenia. Psychiatry Clin Neurosci. 2004;58:89-91.

12. Kassam A, Glozier N, Leese M, Loughran J, Thornicroft G. A controlled trial of mental illness related stigma training for medical students. BMC Med Educ. 2011;29;11:51.

13. Llerena A, Caceres MC, Penas-Lledo EM. Schizophrenia stigma among medical and nursing undergraduates. Eur Psych. 2002;17:298-9.

14. Pintard PJ, D'Sa A, Sciascia S. Medical students' attitudes about mental illness. Psychiatr Serv. 2012;63:836

15. Korszun A, Dinos S, Ahmed K, Bhui K. Medical student attitudes about mental illness: does medical-school education reduce stigma? Acad Psychiatry. 2012;36:197-204.

16. Mas A, Hatim A. Stigma in mental illness: attitudes of medical students towards mental illness. Med J Malaysia. 2002;57:433-44

17. Yadav T, Arya K, Kataria D, Balhara YP. Impact of psychiatric education and training on attitude of medical students towards mentally ill: a comparative analysis. Ind Psychiatry J. 2012;21:22-31.

18. Pinfold V, Thornicroft G, Huxley P, Farmer P. Active ingredients in antistigma programmes in mental health. Int Rev Psych. 2005;17:123-31.

19. Sartorius $N$. latrogenic stigma of mental illness begins with behaviour and attitudes of medical professionals, especially psychiatrists. BMJ. 2002;324:1470-1.

20. Alwis A, Perera R, Vasantha HL, Henegama T, Fernando S. The attitude of medical students towards the mental mentally ill: the impact of a clinical attachment in Psychiatry. Sri Lanka J Psychiatry. 2012;3:12-5.

21. Taylor SM, Dear MJ. Scaling community attitudes toward the mentally ill.
Schizophr Bull. 1981;7:225-40

22. Marques JG, Barbosa AA, Queiroz L, de Oliveira SM, Lopes AC, Carno MJ, et al. Saúde mental também se aprende: atitudes de adolescentes estudantes do ensino secundário perante a doença mental. Rev Psiquiatria. 2012;24:23-32

23. Amini $H$, Majdzadeh $R$, Eftekhar-Ardebili $H$, Shabani A, Davari-Ashtian R. How mental illness is perceived by Iranian medical students: a preliminar study. Clin Pract Epidemiol Ment Health. 2013;19;9:62-8.

24. Mino $\mathrm{Y}$, Yasuda N, Tsuda T, Shimodera S. Effects of a one-hour educational program on medical students' attitudes to mental illness. Psychiatry Clin Neurosci. 2001;55:501-7.

25. Reddy JP, Tan SM, Azmi MT, Shaharom MH, Rosdinom R, Maniam T, et al. The effect of a clinical posting in psychiatry on the attitudes of medical students towards psychiatry and mental illness in a Malaysian medical school. Ann Acad Med Singapore. 2005;34:505-10.

26. Chung KF. Changing the attitudes of Hong Kong medical students towards people with mental illness. J Nerv Ment Dis. 2005;193:766-8.

27. Altindag A, Yanik M, Ucok A, Alptekin K, Ozkan M. Effects of an antistigma program on medical students' attitudes towards people with schizophrenia. Psychiatry Clin Neurosci. 2006;60:283-8.

28. Kerby J, Calton T, Dimambro B, Flood C, Glazebrook C. Anti-stigma films and medical students' attitudes towards mental illness and psychiatry: randomized controlled trial. Psychiatric Bulletin. 2008;32:345-9.

29. O' Connor K, Brennan D, O' Loughlin K, Wilson L, Pillay D, Clarke M, et al. Attitudes towards patients with mental illness in Irish medical students. Ir J Med Sci. 2013;182:679-85.

30. Galka SW, Perkins DV, Butler N, Griffith DA, Schmetzer AD, Avirrappattu $G$, et al. Medical students' attitudes towards mental disorders before and after a psychiatric rotation. Acad Psychiatry. 2005;29:357-61.

31. Aghukwa CN. Medical students' beliefs and attitudes towards mental illness: effects of a psychiatric education. Acad Psychiatry. 2010;34:679.

32. Williams JA, Liu N, Afzal K, Cooper B, Sherer R, Morgan I, et al. Positive attitudes towards psychiatry among Chinese medical students. Int J Soc Psychiatry. 2014;60:21-9.

33. Summerfield D. Does psychiatry stigmatize? J Royal Soc Med. 2001:94:148-9.

34. Stuart $\mathrm{H}$. Media portrayal of mental illness and its treatments: what effect does it have on people with mental illness? CNS Drugs. 2006;20:99106.

35. Garyfallow G, Adamopoulou A, Lavrentiadis G, Giouzepas J, Parashos A, Dimitriou E. Medical students' attitudes towards psychiatry in Greece: an eight-year comparison. Acad Psychiatr. 1998;22:92-7.

36. Faulkner A. Stigma is still a significant concern in mental health. Ment Health Today. 2013;17

37. Pellegrini $\mathrm{C}$. Mental illness stigma in health care settings a barrier to care. CMAJ. 2014;186:E17.

38. Marques JG, Machado D, Ouakinin S, Fiqueira ML. Vulnerability to stress and psychopathology among third year medical students. Int $J$ Clin Neurosc Ment Health. 2015;2:3 


\section{Stigma and Attitudes Towards Psychiatric Patients in Portuguese Medical Students}

Acta Med Port 2015:28:715-719

Publicado pela Acta Médica Portuguesa, a Revista Científica da Ordem dos Médicos

Av. Almirante Gago Coutinho, 151

1749-084 Lisboa, Portugal.

Tel: +351218428215

E-mail: submissao@actamedicaportuguesa.com

www.actamedicaportuguesa.com

ISSN:0870-399X | e-ISSN: 1646-0758

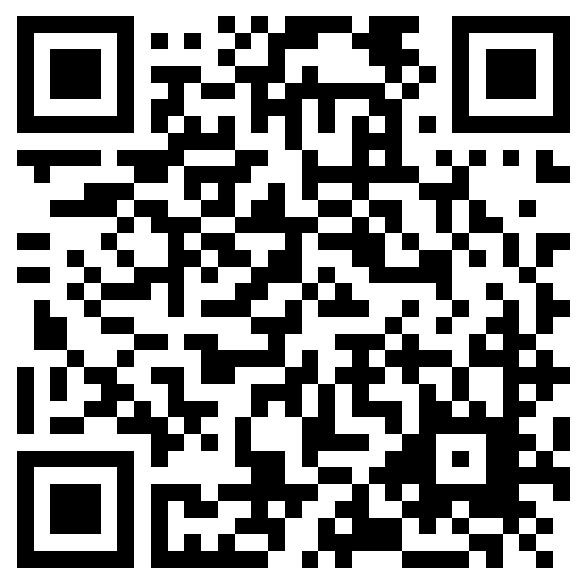

